\title{
The Effect Of The Country Of Origin In Evaluation Of Foreign Oriented Products And The Mediation Role Of Brand Loyalty: Kazakhistan Example
}

\author{
Assist. Prof. Dr. Mustafa KARACA Inonu University Turkey \\ Assist. Prof. Dr. Ali BAYRAM Hitit University Turkey \\ Assist. Prof. Dr. Durdu Mehmet BİÇKES Nevsehir Haci Bektasi Veli Univesity Turkey \\ Research Assist. Caner ÇAKI Inonu University Turkey
}

\begin{abstract}
In this study, it is aimed to determine the effect of the country origin in the evaluation of foreign productsand the mediating role of brand loyalty between them. The datas were obtained as a result of the questionnaires applied to the consumers living in Kazakhistan after the literature survey. According to the obtained datas, it has been understood that the brand loyalty has a partial mediating effect. There have been applied 414 questionnary to the respondents. But294questionnaires returned and 247 questionnary were analyzed. The results have showed that consumers have been influenced by the knowledge of the country of origin when evaluating products of foreign origin and brand loyaltyhas decreased the effect of country of origin.
\end{abstract}

Keywords: Country Origin Effect, Brand Loyalty, Foreign Oriented Products, Marketting, Kazakh Consumers

\section{INTRODUCTON}

With the transition from the traditional marketing concept to the modern marketing concept, it is inevitable for the consumer not to get every production and therefore to create a fierce competition atmosphere in the sense of product appreciation among the companies. As a result of the situation, extremely sophisticated sales and promotion techniques have made intensive efforts to get dozens of products with different advantages compared to each other. The consciousness of the consumers has come out as a different argument arising parallel to this situation. The conscious consumer has been creating a profile that has explored more, tried harder and tried to maximize the benefits that he/she will achieve.In the light of all these living developments, consumers are influenced by many factors while making their preferences. One of them is the origin country effect, which is expressed as the origin information of the product. The perception and attitude of the consumer regarding the country where is produced the product he/she consumes is an element that is directly influenced by the consumer's preferences. According to some thinkers who are driven by the assumption that consumers always behave rationally in the face of modern marketing techniques, although the effect of the country of origin is not very effective in preferences, the centered thoughts of the origin of the product can sometimes even cause a very useful product to be out of favor.The effect of country of origin is an influence which expresses all the thoughts and beliefs related to the origin of the product and which directly affects the consumer in the preference of foreign products.In this study, It is investigated how effective the role of the origin country effect on evaluating foreign products can be against brand loyalty. In other words, when considering the influence of the country of origin in the consumer preferences in consuming foreign products, how does brand loyalty influence this effect? The question that has been put on and the main purpose of the study is to lighten this question. The secondary purpose is to determine whether brand loyalty is influential in the consumption of foreign products. In this context, various expressions were directed to consumers with a disposable income and a certain education level with the help of a question form, and the answers were analyzed with the help of a statistical package program to try to reach the aim of the study. Analyzes have showed that consumers are influenced by the origin country while they prefer foreign products, but consumers who are brand loyalty cause the weakness of the origin country effect. In this respect, the study will make a particularly different contribution especially to domestic and foreign literatures, as far as the part scanned.

\section{PRODUCT ASSESSMENT CONCEPT}

There are many alternatives for purchasing any product for consumers of developed and developing countries. In consumer perceptions, the effect of country of origin has been extensively investigated outside of the country, for example Schooler 1965; Samiee 1994; Like Peterson and Jolibert 1995. Consumer and marketing researchers have been making an enormous effort in understanding and clarifying this issue and in 
identifying the factors that influence consumers' perceptual decisions. It has been expressed that the effect of the country of origin has become an attitude that is used by consumers in the evaluation of foreign products (Johanson et al., 1985, Hong and Wyer, 1990). Another point is that the effect of the country of origin can be seen in consumers' evaluations of foreign products and in their consumption of foreign products (Erickson et al 1994, Han 1989). Third, while the influence of the country of origin can play a sourcing role in the classification of countries, consumers can directly influence their attitudes towards the brand of any country by valuing it (Wright, 1975).Previous research has shown that the origin country knowledge of products affects consumers' judgments about commodities (Han 1989, Hong and Wyer 1991, Verlegh and Steenkamp 1999). The purchasing decisions and behaviors of the consumers take place in the context of some information. Purchases made without accurate and effective information have some inherent risks. Consumers seeking a way to reduce psychological stress by reducing income are developing various solutions. In the evaluation of products of different origin and quality, consumers use all kinds of information about the product intensively in the selection of alternatives and finally in the realization of buying behavior. In many studies, the knowledge of the country of origin affects consumers' evaluations of products and plays a role as an important factor in the consumer's tendency to products to make a judgment about the product (Liefeld 1993; Peterson and Jolibert 1995; Verlegh and Steenkamp 1999.)There are many factors that influence the buying behavior of individuals. Among them, the leading factors can be listed as follows; product quality and design, color, packaging, brand, price, after-sales technical services, image of sales store, attitudes and behaviors of marketing staff, environmental responsibilities during product production and the effect of image of origin country. According to some researchers, these factors can be subjected to a dual separation as internal and external factors (Olson and Jacoby, 1972).Consumers are affected by multiple factors, either in purchasing decisions or in the product evaluation process. Although these factors can give many examples, the effect of the country of origin may be one of these factors. In particular, it is possible to give important information about the origins of production, origin, product endurance, usefulness, in short, quality when evaluating foreign branded products. Experiences of consumers on products they have chosen affect the behavior of new product purchases (Burke et al., 1992; Huber and Zwerina 1996).Consumers are faced with any alternatives at the point of decision making and every factor that influences the decision mechanism goes to evaluation. This situation makes the decision-making process more complicated and inevitable. From the feeling of need to resolve this complexity in the decisionmaking process, consumers evaluate all the factors that influence the decision-making process by defining a focal point and try to solve the complexity of the event. The decision-making process of decision-making by consumers generally is the knowledge of the country of origin (Huber and Puto 1983; Ratneshwar et al., 1987; Sheng et al., 2005). Consumers are under the influence of a lot of information while they are in purchasing decision and behavior. Especially today, which is called as information age, many unnecessary, important and insignificant information is aimed at the consumer in bombardment. Consumers who have to use this information correctly and quickly in order to be able to make effective decisions are going to simplify the decision-making process with the help of some mental processes in order to get rid of the mental confusion they are in. The effect of the origin country, which has been introduced at this point, has an important role in the purchasing decision and behavior of the consumer. By simplifying the process, they can make quick and correct decisions. If consumers do not have a lot of knowledge about the use, quality and characteristics of the product they will buy, their purchasing behavior becomes difficult and requires extra information (March 1978; Savage 1954). The disparity in development between countries and the image that is thought to be intrinsic to this difference leads to different perceptions and evaluations of products belonging to different countries in global markets. Consumers are acted with various motives while evaluating domestic and imported products. When choosing domestic and foreign products, consumers may be influenced by a number of subjective factors such as nationalism, racism and the point of view on the domestic products and the point of view on the foreign products are different. Domestic products may be more popular due to the policy of domestic goods. It is also clear that some of the studies in the lacquer literature have reported this opinion in the opposite direction. Particularly, it has been determined that consumers prefer products with foreign products with the influence of values such as quality and prestige (Papadopoulos et al., 1990). In a research conducted, it has been revealed that American consumers feel more prestige if they use Japanese and German products (Chao and Rajendran, 1993).

\section{THE EVALUATION OF FOREIGN ORIENTED PRODUCTS} AND THE EFFECT OF COUNTRY OF ORIGIN

The first study on the origin country effect was made by Curtis Reierson in 1966. Reierson was followed Akira Nagashima 1970, Bennister and Souders 1977, Cattin, Lohnes and Jolibert 1982 and Garland and Crawford 1986, respectively. The literature is predominantly based on Nagashima's work. In Turkey, the work of Zeki Seyda Deligönül 1976 and Arzu Şanlıer took place in the literature as the study of the effects of the first country of origin. The origin country effect was first conceptualized by Nagashima (1970) in the late 
1960s. In Nagashima's work, the consumer's influence on the country of origin means that the consumer combines them with a picture, name, reputation and a stereotype attached to the products of certain countries by the producer. This image is formed by various variables such as a product representing the class, national character, economic and political history, history and traditions. Henceforth, the diversity of the literature has produced the concept of the influence of the country of origin. Samiee (1994) suggests that the impact of the country of origin is a result of an effect made by the country's origin on the service of a common product supported by consumers. There are many different sources in this effect. These include experiences about products, personal experiences, information about the country, political beliefs, ethnocentric tendencies, fears and others.Consumer behavior and international marketing are expressed in the literature by a number of studies that have influenced the buying decision or behavior of the origins of the product origin, origin, during the evaluation of foreign products by consumers. This situation is called the origin country effect in the literature. A number of studies have been conducted in foreign literature, which show that the effect of the origin country influence consumers' perception, attitude development and purchase decision and behavior (Agrawal, Kamakura, 1999). The most important indicator of the country of origin is the "made in ......" on the product. This phrase makes use of the previous experience in the product selection process to make the product associate with the consumers such as price, quality and ease of use. It influences consumer's subjective judgments about products, perceptions, attitudes and beliefs and incorporates them into the decision-making process (Han 1989).

The effect of the country of origin has gained importance through the increase in the quality and quantity of international trade and the products of the country which is the subject of it, and has included itself in the scientific literature. External marketing offers many kinds of products to consumers. This situation has made the evaluation and selection processes of consumers very complicated. Knowledge of the origin country has an effective precaution in simplifying this complex process (Bilkey 1993). Intensive competition in international trade and knowing how consumers choose products according to the basics is vital for producers who are addressing consumers. For this reason, knowledge of the country of origin and its impact on consumers is a matter that needs to be explored both for consumers and producers (Kottler et al., 1993). Consumers use the internal and external information of the product while evaluating the products. While all the physical characteristics of the product constitute the internal information part, the information such as the origin of the product, the price and the importer form the external information part. Origin country information is also an important information in the external information part of the product, especially for consumers (Klein et al 1998, Han and Terpstra 1988).In addition, the use of external information is increasing, when internal information is not a very satisfactory guide (Huber and Mc Cann 1982). With the development of commerce over the Internet, the information about the product is usually external, which increases the importance of the knowledge of the country of origin. The effect of the country of origin is a positive or negative effect that affects the behavior of the country in which the product is produced, the consumer's behavior in the product selection process and the subsequent selection process (Terpstra, 1988). The influence of the country of origin is a portrait of the country in which the product is produced for the consumer, the consumer is a stereotype of reputation. These are created by variables such as a sample product, national characters, economic and political history, traditions in history (Nagashima, 1970). The effects of the country of origin and the studies in the literature emphasize that the factor of origin is effective in evaluating the products (Terpstra 1989). In the case of industrial products, the effect of the origin country can effect on the perceptions of related consumers with the quality of products (White and Cundiff 1978). " Made in ...." is a marketing strategy in international markets to build public opinion (Bilkey and Nes 1982). Studies conducted in this area are generally focused on showing consumer perceptions of the quality of products produced in foreign countries (Leonidau et al., 1999, Bilkey and Nes, 1982, Peterson and Jolibert, 1995). According to the results of a study conducted by Leonidau et al. In 1999, Bulgarian consumers are demanding more German products, followed by Hong Kong, Singapore, Indonesia, and Indie countries respectively. Cattin (1982) notes that Americans prefer West German products to products from England and France. Darling and Kraft (1977) show that Finnish consumers prefer West Germany and England products more than their French counterparts. In another study, Baumgartner and Jolibert (1976) state that French consumers firstly prefer domestic products followed by German and British products respectively. Zain and Yasin (1997) found that Uzbek consumers perceive Japanese and American goods as better quality than the goods of less developed countries like India. Parallel results have also been presented by Kaynak and others (1995) for Azerbaijani consumers and by Lascu and Babb (1995) for Polish consumers.

The effect of the country of origin is an effect that affects purchasing behavior of consumers in developed and developing countries, particularly for different product classes, which makes them more likely to be affected by the consumption of industrial products. Attitudes change over time and do not show a constant character among the countries. There is a more positive trend towards indigenous crops, with the exception of some developing countries in all countries. The low-quality products of developed countries are 
perceived as more quality than the quality products of the developing countries. This situation naturally gives the developed countries a competitive edge.According to literature survey, demographic characteristics of consumers can affect the nature of origin country effect. For example, it has been determined that older consumers and females demand more products of foreign origin (Schooler, 1971; Johanson et al., 1985). In another study, it was stated that university graduates were more likely to approach foreign products than did less educated consumers (Anderson and Cunningham, 1972; Domoff et al., 1974; Wang, 1978). In a survey on Bulgarian consumers, it was found that demographic characteristics did not play a very modifying role in evaluating foreign products (Leonidou et al., 1999).There is a close relationship between the origin country and the import country. One is a cultural term and the other has a significant impact on consumer perceptions. The proximity to the countries encourages perception of the product of that country as good (Bilkey and Nes, 1982, Samiee, 1994, Wall and Reslop, 1986, Wang, 1978). Similar results apply to countries that are politically and economically close (Gaedake, 1973, Iyer and Kalita, 1997). In addition, the impact of the country of origin is a valid effect in the evaluation of industrial products as well as in consumer goods (Liefeld, 1993).The impact of the country of origin has an important role in the assessment of foreign products. Consumers are influenced by many product categories. Regarding the effect of demographic variables, there is no complete association in the literature. However, the consensus on the literature is that there is a more positive and good perception of the products of the developed countries than the products of the developing countries. The origin country effect refers to the attitudes of the other country consumers in regards to the general perception of the products of the country concerned (Zhang, 1996), considering the level of development of an country, marketing strategies and the quality of its products. Origin country information is a summary, relevant information on the origin of the product concerned, an indicator, or even a more evolved image.Consumers use the information, perceptions, attitudes, beliefs and intrinsics they have about the origin of the product directly, while other products, like the origin of the product, evaluate the products they do not have much information about. This concept has passed through the literature as a halo effect. In other words, while evaluating a product for which they do not have information about consumers, another product belongs to the same product originates from the knowledge and experience of the same product origin (Han and Terpstra, 1988). The previous conviction of the consumer who will try a new German car is "the quality of German cars" can be influential. When the process of formation of the root effect of the country of origin is examined, it is appropriate to mention the influence of some factors. These factors can be summarized as follows; Personal experience with the product, experimentation with consumption of other products of origin, information and beliefs about the origin of the product, newspapers and magazines, radio and television (Chinen et al., 2000).

The effect of the country of origin affects consumers in four different dimensions. The information of the origin of the product may cause some different information to appear in the evaluation process of the product. Second, it may be an objective approach to the quality and image of the product, without regard to other product information. Third, the consumer, who has knowledge, beliefs and experience about the origin of the product before, can be influenced while evaluating the current product. In the final dimension, the information of the origin country can provide the attention of the consumer in the process related to the decision-making and buying behavior of the product. When literature review is done, it is stated that some researches have not taken into account the concept of country of origin and some consumers have not taken advantage of it. A study conducted in 1986 emphasized that the vast majority of participants under the age of 36 did not care about or use the knowledge of the country of origin (Hugstad and Durr, 1986). Of course, the studies that reveal that consumers consider the influence of the origin country and make use of it, constitute a large part of the literature.Depending on the demographic characteristics, attitudes, beliefs, perceptions and other personal characteristics of the consumers, the effect of the country of origin has great influence in determining the purchasing decisions and behaviors and preferences of the consumers (Sancakli, 2000). The attitude and beliefs of the consumers in the attitudes and behaviors against the products of foreign origin are too much to deny (Erickson et al., 1984). It is stated that the origin country effect has a decreasing trend as it goes from consumer perception to behavior and from attitudes towards behavior, so that the effect of the origin country has different effects on the purchasing decision and behavior of the consumer at every point of the process (Sancakli, 2000: 47).In cases of adequate and reliable knowledge, the rate of consideration of the effect of the origin country falls. Consumers also take into consideration factors such as brand, guarantee conditions, product form, content, packaging, and store design in the decision process as well as the origin country effect (Chao and Gupta, 1995).

It has an important role in consumer perceptions of the country of origin and consumption of the products of the country concerned (Chao and Rajendran, 1993). The effect of country of origin on consumers' decision making and purchasing behavior is individual and individual differences. While some consumers are not exposed to this effect, they use it intensively. Individuals who use the origin country influence use them at different levels (Heslop and Popodopoulos, 1993). Individuals with low educational backgrounds and elderly people use knowledge of the country of origin higher than others (Anderson and Cunningham, 1972, Sharma, 
1987).

According to a study by Erickson, Johansson and Chao (1984), Mexican consumers are showing a qualityoriented perspective when evaluating their products. They find the German cars superior, and if they approach the economical point of view, they find Japanese cars superior. In a survey by Johansson, Douglas and Nonaka (1985), Korean consumers find Korean cars superior when considering the distance traveled by one liter of vehicle, while keeping their German cars better when it comes to driving comfort and comfort. Consumers' past experiences on consumption are influencing the use of knowledge of the country of origin. Inexperienced individuals are more likely to be exposed to the impact of the country of origin (Cordel, 1992). In addition, inadequate knowledge of the product increases the likelihood of being influenced by the country of origin (Maheswaran, 1994).Consumers' attitudes and perceptions of the origins of a product can vary over time. A sympathetic perspective can later be developed on a country that has previously been subjected to hatred and hatred (Darling and Wood, 1990). Consumers of different countries can prioritize different kinds of information while evaluating foreign products. Consumers of some countries may never use it while others use the knowledge of the country of origin more. This situation can vary from country to country. Consumers can use subjective and emotional criteria rather than objective criteria when evaluating foreign products. Bad emotions that are fed against the origins of the original product, experienced past negative experiences, etc. Can be effective. The effect of the country of origin can also vary from product to product. Negative attitudes towards another product can be developed while positive attitudes towards a product of the same country can be developed (Han, 1990).Products originating from a specific country can be preferred to products from other countries. It is known that the consumers have a more positive view that they have different attitudes to the country from the country (Chinen et al., 2000). The products of the developed countries can be preferred to the products of the less developed countries in the developing world (Gaedake, 1971, Samiee, 1994). Especially the consumer attitudes developed to the products of industrial countries are relatively positive (Heslop and Popodopoulos, 1993). It is not negatively affected due to the negative image of the country which is known and famous brand origin. It is not subject to any negative evaluation by the consumers (Tse and Gorn, 1993). The two countries that have trade relations are responsible for the positive evaluation of their beliefs, ideas, ideological and ethnic closeness products (Zhang, 1996).

The physical closeness of the countries to each other causes consumers to encounter positive evaluations of product exchanges between them, even if they are stakeholders of the same region. It was understood that Chinese consumers rated American products more positively than South Korean products (Anderson and Engeldow, 1977).

\section{BRAND LOYALTY}

Brand; is a term, symbol, name, or a combination of them, which is different from their competitors' counterparts, which are produced by any business or which are offered to the market by many brokerage houses and which provide an identity to the services. Brand provide benefits to the customer in terms of ensuring selection ease, providing information and confidence in terms of quality, ensuring that goods are easily repaired in case the need for spare parts can be easily reached when they are in demand, increasing the qualities of the goods offered and raising the goods by creating intermediary pressure .

In the brand loyalty, consumers continue to buy a brand they already bought and tested. It is important for the business to uncover whether brand equity is genuine or fake brand loyalty. While brand addictive is paying attention to the true brand attribute, thefalse brand addictive is affected by issues such as discount coupon, instore shelf arrangement and it can easily change the brand which is used depending on them (Avcllar and Akın, 2007).

Brand loyalty is defined as the positive attitude (preference) and behavioral response of the consumer to one or more brands within a certain category within a certain period (Ersoy, 2007). This can be understood from the definition of brand equity as two aspects can be examined:

(1) (Behavioral Brand Loyalty): Customers behave as they always do with the same brand. Repeated purchases represent the purchase frequency of a particular brand, by the total number of purchases of other brands or by purchase quantities. Continuing to receive services from the same company, development of relationships from all angles are the examples of recall adherence behaviors.

(2) (Attitudinal Brand Loyalty): Emotions are influential in the formation of a person's commitment to a product, service, or company. Even with these feelings, the degree of loyalty of the person can be determined (Back et al., 2003). Ensuring brand loyalty is not based on strategies such as developing programs for the ongoing customers or giving gifts to those customers, but also factors such as loyalty and trust Winning. Research shows that brand loyalty is not only a recurrence of buying behavior, but also a multifaceted attitude towards branding. Bentler and Speckart found in 1981 that attitudes have priority over behavior.Olson concluded that a negative change in attitudes resulted in the majority of customers shifting to other brands, thus changing attitudes was a good indicator for brand loyalty and brand change (Back et al., 2003). The fact that 
consumers show special purchasing behavior against different brands reveals the importance of brand dependency concept. Consumers' positive attitudes towards specific brands include demographic, economic or psycho-graphic characteristics of the consumer, features of the product and environmental factors (Ersoy, 2007)..Commitment is intensified and participated in the tendency to re-purchase goods or services previously known or recommended in the future. Thus, even if environmental conditions and marketing efforts potentially affect the behavior of the direction, it will lead to the purchase of the brand or being dependent on multiple causes. Brand dependency;

1. Some consumers tend to buy a certain brand regularly and consistently.

2. The tendency of consumers to continue to buy a brand they have already bought and tested.

3. The positive attitude (preference) and behavioral response of the consumer to one or more brands in a product category over a period of time.

One of the most used definitions in determining brand equity, especially in experimental research, is the ratio of total purchases within a particular product type to the most purchased brand within that type. Since the proportion of purchases is numerical, it is also mentioned that brand dependency is expressed as mathematical models. After the odds have emerged, double or triple brand dependency is also analyzed. Analyzes are performed as time series containing the distribution of brands purchased by households over a period of time. Consumer preferences as well as consumer acquisitions should be included in the definition of brand equity. The condition that the consumer has a positive hold on the brand as well as a re-purchase of the brand is a real dependence. Behavioral and brand commitment This model, in which the segments based on the holding are combined, provides superiority to traditional models based solely on purchasing data. In addition, brand loyalty is not considered as a general concept by this method, but it is regarded as a matter based on the product characteristic.

\section{METHODOLOGY}

\section{The Purpose and Hypotheses of Research}

The purpose of this study is to examine the relationship between the origin country effect and the evaluation of foreign products, and to reveal the mediating role of brand loyalty when examining this relationship. The hypothesis of research in this framework is as follows.

H1: The effect of thecountry origin is influential in the assessment of products of foreign origin.

H2: The country origin effect has an effect on brand loyalty.

H3: Thebrand loyaltyhas effect on the evaluation of foreign origin products.

H4: The effect of country origin has effect on evaluation of foreign origin products and brand loyalty has an mediating role.

\section{The Research Model}

The research model structured within hypotheses established to examine the mediating role of brand equity in the evaluation of foreign origin products of the origin country effect is as shown in Figure 1.

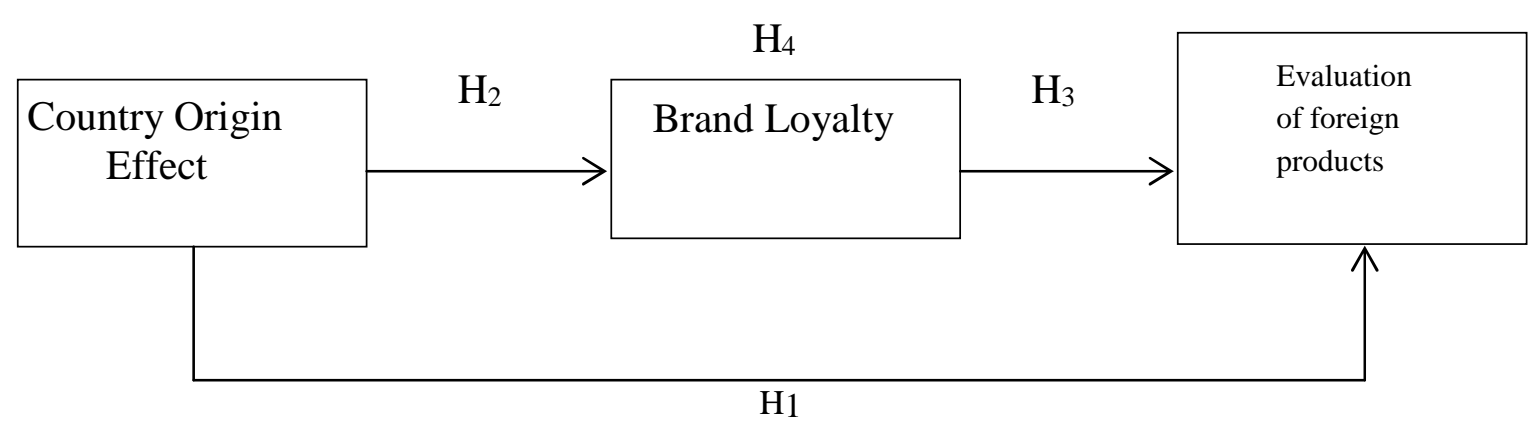

Figure 1: Research Model 


\section{The Method and Sample of The Research}

Research consists of two phases; theoretical and practical. At the theoretical level, the concepts of origin country influence, products of foreign origin and brand loyalty have been examined based on secondary source data. In the application phase, a questionnaire was prepared based on theoretical information.

The questionnaire form was prepared for the benefit of the scale. The five-point Likert scale for the questionnaire study was based on 1: Strongly Disagree, 2: Disagree, 3: Neither Strongly Agree, 4: Agree, 5: Strongly Agree. With the prepared questionnaire, it was tried to measure the degree of participation of the participants in each expression.Consumers are the main mass of the research. Due to the fact that there are too many people in the sample, a complete count can not be made. The questionnaires were applied to a total of 414 persons. 294 of the questionnaires were returned, but 47 were missing because of missing answers. A total of 247 surveys were considered valid. The recycling rate of the questionnaire is $59.67 \%$. The data collected from the primary source with the help of questionnaire were evaluated with the help of SPSS 18 package program.

\section{THE RELIABILITY TEST RESULTS}

It is necessary to evaluate the reliability and validity of the data before the hypothesis of the research purpose is tested. For this reason, reliability and validity analyzes were conducted before the research hypothesis was tested, and the reliability of the scales was determined by the internal consistency method.

An implementation of the internal consistency method is the "alpha coefficient". Alpha coefficient is the most widely used method to test the reliability of the scale and it takes between zero and one. To be able to talk about the reliability of the scale used in the research, the alpha coefficient should be 0.70 or higher (Hair et al., 1998: 118). As a result of the reliability analysis, the reliability of the scale of evaluation of foreign products, 813 , the reliability of the country of origin scale, 883 , and the reliability of the brand loyalty scale, 786 were determined. The internal consistency ratio found as a result of the reliability analysis exceeded 0.70 , which is the lower limit for reliable acceptance of scales.

\section{The Findings Regarding Mean, Standard Deviations and Correlation Values of The Research Variables}

After determining that the scales used in the study were reliable, the mean values of the data, standard deviations were calculated and the correlation values between the variables were examined. Correlations between variables, mean, standard deviation and variables are given in Table 1.

Table 1: Correlations Between Variable Average, Standard Deviation and Variables

\begin{tabular}{|l|l|l|l|l|l|}
\hline Variables & Average & Standard deviation & $\mathbf{1}$ & $\mathbf{2}$ & $\mathbf{3}$ \\
\hline 1-Foreign Products & 3,3169 &, 61688 & 1 & & \\
\hline 2-Origin Country Effect & 2,1155 &, 96487 &, $305^{* *}$ & 1 & \\
\hline 3-Brand Loyalty & 2,9573 & 1,14150 &, $286^{* *}$ &, $346^{* *}$ & 1 \\
\hline
\end{tabular}

When the answers given by the participants were examined, it was determined that the highest average belonged to the evaluation of foreign products $(3,32)$.Correlation analysis was used when the relations between the variables were determined in the study. Correlation analysis is widely used in marketing research. This analysis coefficient, which is used to reveal linear relationships, represents a value ranging from -1 to +1 (Nakip, 2003: 244). When the results of the correlation analysis were examined, it was found that there was a positive, weak ( $305 * *)$ between the evaluation of foreign products and the effect of the country of origin, a positive correlation between the evaluation of foreign products and brand loyalty, a very weak $(286 * *)(346$ **) were found to be significant.

\section{Testing The Hypotheses}

At this stage of the research, regression analysis was conducted to test the research hypotheses. Regression analysis is a statistical technique that tests the relationship between a dependent variable and one or more independent variables (Nakip, 2003: 227). If there is a dependent and an independent variable in the regression model, simple regression analysis (a.ge..228) And if there is more than one independent variable, it is called multiple regression analysis (a.ge .: 247). The results of the ANOVA analysis, which tests the validity and significance of the models of each scale, are given below. $\mathrm{R}$ values that show the regression coefficients and R2 values that explain the variation of independent variables on dependent variables. In addition, when the results of the research hypotheses are examined, it is seen that the relation between the independent variables and the dependent variables are shown to Beta coefficients and accepted hypotheses The regression models are given in Table 2. 
Table 2: Regression Analysis Results Regarding Hypotheses

\begin{tabular}{|c|c|c|c|c|c|c|c|c|}
\hline Variables & Beta & $\mathrm{t}$ & Sig. & $\mathrm{R}$ & $R^{2}$ & F & Sig.F & Result \\
\hline \multicolumn{9}{|c|}{ H1: The country origin has an effect on the evaluation of foreign origin products. } \\
\hline Stable & 2,925 & 29,692 &, 000 & & & & & \\
\hline \multirow[t]{2}{*}{ Origin Country Effect } &, 115 & 4,358 & ,000 & & & & & \\
\hline & & & &, 286 &, 082 & 18,990 &, 000 & Accepted \\
\hline \multicolumn{9}{|c|}{ Regression Model Y=2,925+,115(Country Origin Effect) } \\
\hline \multicolumn{9}{|c|}{ H2: The country origin has an effect on brand loyalty. } \\
\hline Stable & 2,147 & 12,337 &, 000 & & & & & \\
\hline \multirow[t]{2}{*}{ Origin Countrv Effect } & 383 & 5.112 & .000 & & & & & \\
\hline & & & & 333 & 111 & 26,134 & 000 & Accepted \\
\hline \multicolumn{9}{|c|}{ Regression Model Y=2,147+,383(Origin Country Effect) } \\
\hline \multicolumn{9}{|c|}{ H3: Brand loyalty has an effect on the evaluation of foreign products. } \\
\hline & 2.868 & 24.600 & .000 & & & & & \\
\hline \multirow{2}{*}{ Brand Loyalty } &, 152 & 4,106 &, 000 & & & & & \\
\hline & & & & 270 & ,073 & 16,863 & 000 & Accepted \\
\hline
\end{tabular}

First, statistical validity and significance of the hypotheses established in regression analysis were tested. When the results of the ANOVA analysis that tests the validity and significance of the hypotheses are examined, the $\mathrm{F}$ values are 18,990 for the first model; 26,134 for the second model and 16,863 for the third model. It is seen that $p$ values of significance values are $p=0,000$ for all models. As the result of the ANOVA analysis, the value of $\mathrm{F}$, which measures the validity of the models, is greater than \pm 1.96 in all models and the value of $\mathrm{p}$, which measures the meaning of the models, is less than 0,05 in all three hypotheses. Therefore, the models established for the purposes of the research are statistically significant and valid hypotheses .After analyzing the significance and validity of the hypotheses, we have looked at the R2, which is the regression coefficients $\mathrm{R}$ and independent variables, indicating the relationship between the independent variables and the dependent variable for the three models, and the variation of the independent variables over the dependent variables. For the first model, the $\mathrm{R}$ value is 0.286 and the $\mathrm{R} 2$ value is 0.082 , for the second model, the $\mathrm{R}$ value is 0.333 and the $\mathrm{R} 2$ value is 0.111 , for the third model, the $\mathrm{R}$ value is 0.270 and the $\mathrm{R} 2$ value is 0.073 . In this case, it is possible to mention the existence of a moderate relation between dependent variables and independent variables for the three models. Because $\mathrm{R}$ is expected to take a value between 0 and 1 . It is predicted that the closer to $\mathrm{R}$ value 1 , the closer a strong relation 0 is. On the other hand, when the results of the research hypotheses are examined, there is a relation between the independent variables in the three hypotheses and the variables in the hypotheses from the beta coefficients indicating the relation level between the dependent variables and $\mathrm{H} 1, \mathrm{H} 2$ and $\mathrm{H} 3$ hypotheses were accepted.A four-step regression analysis, as proposed by Baron and Kenny (1986), was conducted to explain the mediating role of brand equity in the impact of the origin country effect on the assessment of foreign origin products. According to this method, there are four conditions for the mediation effect to be mentioned (Baron and Kenny 1986: 1173-1182):

1. The argument must be an effect on the intermediate variable.

2. The independent variable must be effective on the dependent variable.

3. The tool must be a significant influence on the dependent variable. 4. The regression coefficient (Beta value) of the independent variable on the dependent variable decreases when compared with the first equation, while the mediator variable has a significant effect on the dependent variable when the effect of the variable is controlled and the agent is inserted into the regression together with the independent variable.Previous regression analyzes have shown that the first three conditions are met. Multiple regression analysis was performed between the dependent variable and the independent variables in order to see whether the fourth condition was satisfied. The results of the analysis are as shown in Table 3. 
Table 3: Regression Analysis Results Regarding Hypotheses

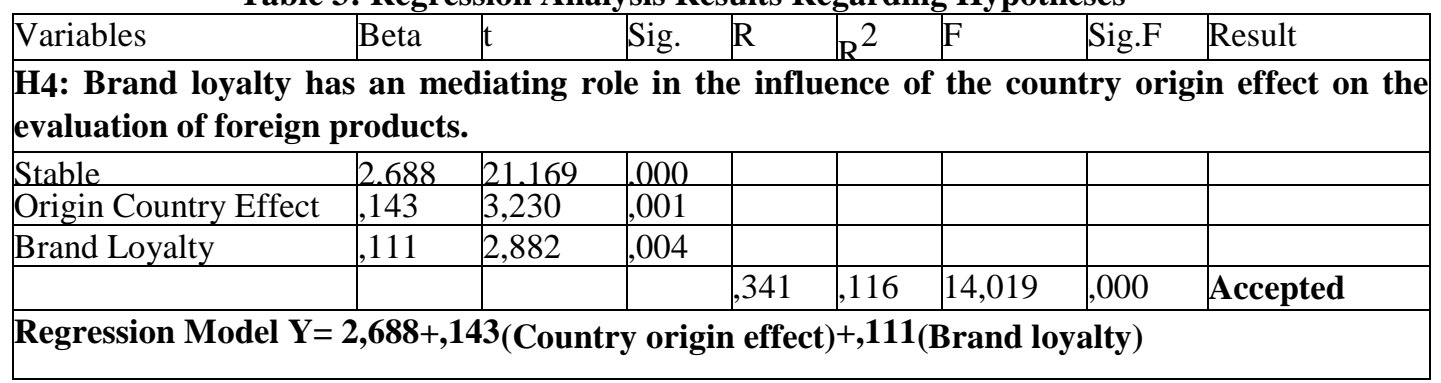

First, the hypothesis established in regression analysis was tested for statistical validity and significance. When the results of the ANOVA analysis that tests the validity and significance of the hypothesis are examined, it is seen that the $F$ values are 14,019 . It is seen that $p$ values of significance values are $p=$ 0,000 . The hypothesis established for the purposes of the study appears to be a statistically significant and valid hypothesis, as the ANOVA analysis showed that the $\mathrm{F}$ value, which measures the validity of the hypotheses, is greater than \pm 1.96 and the $\mathrm{p}$ value, which measures the significance of the hypothesis, is less than 0.05.After analyzing the significance and validity of the hypotheses, we have looked at the R2, which is the regression coefficient $\mathrm{R}$ and the independent variables, on the dependent variables, which show the relationship between the independent variables and the dependent variable. The $\mathrm{R}$ value for the hypothesis is 0.341 and the $\mathrm{R} 2$ value is calculated as 0.116 . In this case, it is possible to mention the existence of a moderate relationship between the dependent variable and the independent variables in the hypothesis. Because $\mathrm{R}$ is expected to take a value between 0 and 1 . It is predicted that the closer to $R$ value 1 , the closer a strong relation 0 is.H1 and H4 Hypotheses were examined for the effect of instrument variability and the dependent variable. According to this, the beta coefficient of $\mathrm{H} 4(, 143)$ was found to be lower than the beta coefficient of $\mathrm{H} 1$ (, 185). This indicates that the brand loyalty assumes a partial intermediary role in relation to the origin of the country and the evaluation of the products of the foreign origin.

\section{RESULT}

There are many alternatives for purchasing any product for consumers of developed and developing countries. In consumer perceptions, the effect of country of origin has been extensively investigated outside of our country. Consumer and marketing researchers are making great efforts in understanding and clarifying this issue and in identifying the factors that influence consumers' perceptual decisions. The expressed sentiment is that the effect of the country of origin has become an attitude that is used by consumers in the evaluation of foreign products. Another point is that the effect of the country of origin can be seen in consumers' evaluations of foreign products and in their consumption of foreign products. Third, while the influence of the country of origin can play a sourcing role in the classification of countries, consumers can directly influence their attitudes towards the brand of any country by valuing it. Previous studies have shown that the knowledge of the origin country of the products affects the consumers' judgment and the common sense about the products. The purchasing decisions and behaviors of the consumers take place in the context of some information. Purchases made without accurate and effective information have some inherent risks. Consumers seeking a way to reduce psychological stress by reducing income are developing various solutions.In the evaluation of products of different origins and qualities, in the selection of innumerable alternatives and ultimately in the realization of purchasing behavior, consumers use all kinds of information about the product intensively. In many studies, knowledge of the country of origin has influenced consumers' evaluations of products and has played a role as an undesirable factor in the consumer's tendency to products to reach a judgment on the product. There are many factors that influence the buying behavior of individuals. Among them, those with heavy influence can be listed as follows; product quality and design, color, packaging, brand, price, after-sales technical services, image of sales store, attitudes and behaviors of marketing staff, environmental responsibilities during product production and the effect of image of origin country. According to some researchers these factors can be subjected to a dual separation as internal and external factors. Consumers are affected by multiple factors, either in purchasing decisions or in the product evaluation process. Although these factors can give many examples, the effect of the country of origin may be one of these factors. In particular, it is possible to give important information about the origins of production, origin, product endurance, usefulness, in short, quality when evaluating foreign branded products. Consumers' prior experience with products they choose affects their behavior in purchasing new products.The origin country effect was first conceptualized by Nagashima (1970) 
in the late 1960s. In this work, Nagashima states that consumers combine the origin country effect with a stereotype of a picture, name, reputation adhered to the products of certain countries by a producer or a consumer. This image is formed by various variables such as a product representing the class, national character, economic and political history, history and traditions. From this point on, the diversity of the literature has produced the concept of the influence of the country of origin. Samiee (1994) suggests that the impact of the country of origin is a result of an effect made by the country's origin on the service of a common product supported by consumers. There are many different sources of this effect. These include experiences about products, personal experiences, information about the country, political beliefs, ethnocentric tendencies, fears and others. Consumer behavior and international marketing are expressed in the literature by a number of studies that have influenced the buying decision or behavior of the origins of the product origin, origin, during the evaluation of foreign products by consumers. This situation is called the origin country effect in the literature.A number of studies have been conducted in foreign literature, which show that the effect of the origin country influence consumers' perception, attitude development and purchase decision and behavior (Agrawal, Kamakura, 1999). The most important indicator of the country of origin is the "made in ......" on the product. This phrase makes use of the previous experience in the product selection process to make the product associate with the consumers such as price, quality and ease of use. It influences consumer's subjective judgments about products, perceptions, attitudes and beliefs and incorporates them into the decision-making process (Han 1989). The effect of the country of origin is an effect that affects purchasing behavior of consumers in developed and developing countries, particularly for different product classes, which makes them more likely to be affected by the consumption of industrial products. Attitudes change over time and do not show a constant character among the countries. There is a more positive trend towards indigenous crops, with the exception of some developing countries in all countries. The low-quality products of developed countries are perceived as more quality than the quality products of the developing countries. This situation naturally gives the developed countries a competitive edge. The origin of the product, that is, the origin, is influenced by many researches that influence the purchase decision or behavior of the origin in the evaluation of foreign products by consumers in consumer behavior and international marketing literature. This situation is called the origin country effect in the literature.The effect of the country of origin is an effect that affects purchasing behavior of consumers in developed and developing countries, particularly for different product classes, which makes them more likely to be affected in the consumption of industrial products. Attitudes change over time and do not show a constant character among the countries. There is a more positive trend towards indigenous crops, with the exception of some developing countries in all countries. The low-quality products of developed countries are perceived as more quality than the quality products of the developing countries. This situation naturally gives the developed countries a competitive edge. The impact of the country of origin has an important role in the assessment of foreign products. Consumers are influenced by many product categories. Regarding the effect of demographic variables, there is no complete association in the literature.However, the consensus on the literature is that there is a more positive and good perception of the products of the developed countries than the products of the developing countries. The origin country effect refers to the attitudes of the other country consumers in regards to the general perception of the products of the country concerned, considering the level of development of an country, marketing strategies and the quality of its products (Zhang, 1996). Origin country information is a summary, relevant information on the origin of the product concerned, an indicator, or even a more evolved image.Brand; is a term, symbol, name, or a combination of them, which is different from their competitors' counterparts, which are produced by any business or which are presented to the market by many brokers, and which give an identity to the services. In the brand loyalty, consumers continue to buy a brand they have already bought and tested. Whether brand equity is genuine or fake brand loyalty is crucial to business. While the true brand addictive is paying attention to brand attribute, false brand addictive is affected by issues such as discount coupon, in-store shelf arrangement and it can easily change the brand which is used depending on them (Avcilar and Akın, 2007). Brand provides benefits to costumer in terms of ensuring selection ease, providing information and confidence in terms of quality, ensuring that goods are easily repaired in case the need for spare parts can be easily reached when they are in demand, increasing the qualities of the goods offered and raising the goods by creating intermediary pressure.In this study, the role of the origin country effect in evaluating foreign products was examined and the mediating role of brand loyalty in explaining this role. The basic hypotheses of the study are: a. The origin country effect has an effect on the assessment of foreign origin products; b. The origin country effect has an impact on brand loyalty; c. Brand loyalty has an impact on the assessment of foreign products d. Hypotheses have been accepted that the origin country effect has an intermediary role in brand loyalty in the evaluation of foreign products. The result is that the effect of country of origin is a factor that consumers are paying attention and evaluating the products of foreign origin. This situation is parallel to the results of different studies in the literature. Brand loyalty is also a factor that consumers consider or otherwise influence when evaluating products of foreign origin. These hypotheses of working are parallel to the literature and are expected.The hypothesis that the study-specific 
hypothesis is related to the role of the origin country effect and the mediating role of brand loyalty in the evaluation of foreign products and no literature studies have been conducted in the literature survey. Despite a very detailed screening of this subject, especially in the Turkish literature, there has been no study in this area. As a result of this analysis, this hypothesis has been accepted and it is shed light on new researches. In particular, according to the result, The weight of the origin country effect that consumers consider when evaluating foreign products is diminished by the commissioning of brand equity and brand loyalty alleviates the burden of evaluating the effect of the country of origin.This situation is considered as an original result.According to the datas obtained, it can be said that the level of brand loyalty of the consumers, while evaluating the products of foreign origin, somewhat disables the knowledge of the origin of the product and this situation can be considered as a new result in terms of the business world, consumer researches and brand experts.

\section{REFERENCES}

[1] Anderson, W. and Cunningham W. (1972). "Gauging Foreing Product Promotion"; Journal of Advertising Research; Vol.12, pp.29-34.

[2] Anderson, R. and Engledow, J. (1977). "A factor analytic comparison of US and German information seekers”, Journal of Consumer Research, Vol. 3 No. 4, Spring, pp.185-96.

[3] Avcılar, M. Y. and Akın, M. (2007).Tüketici Temelli Marka Değeri Kavramı, Pazarlama Dünyası, Şubat Sayısı.

[4] Back, K., Parks, S. C. (2003). A Brand Loyalty Model Involving Cognitive, Affective, and Conative Brand Loyalty and Customer Satisfaction, Journal of Hospitality \& Tourism Research, Vol. 27; No. 4, pp.419-435.

[5] Baumgartner, G. and Jolibert, A. (1978). "The Perception of Foreing Products in France"; Advances in Consumer Research 5, Hunt Edit.,pp.603-605.

[6] Bilkey, W.J. and Nes, E. (1982). "Country of Origin Effects on Product Evaluations", Journal of International Bussiness Studies, pp.89-99.

[7] Bilkey WJ. (1993). Foreward. In: Papadopoulos N, Heslop LA, editors. Product country images: impact and role in international marketing. New York: International Business Press.

[8] Burke, R. R., Harlam, A. B., Kahn, E. B., \& Lodish, L. M. (1992). Comparing dynamic consumer choice in real and cmputer-simulated environments. Journal of Consumer Research, 19, pp.71-82(June).

[9] Cattin, P., Jolibert, A., Lohnes, C. (1982) “A Cross-Cultural Study of Made in Concepts"; Journal of International Bussiness Studies,pp.131-139

[10] Cemalcılar, Đ. (1984),Pazarlama, A.Ö.F.Yayınları, Yayın No:312, Eskişehir, 1984s. 260- 261.

[11] Cordell, V.V. (1992). "Effects of consumer preferences for foreign sourced products", Journal of International Business Studies, Vol.23, No.2, pp.251-69.

[12] Darling, J.R., Frederc B.K. (1992). "A Competitive Profile of Products and Associated Marketing Practices of Selected European and Non-European Countries"; European Journal of Marketing,519-531.

[13] Darling, J. R., Wood, V.R.(1990).“A longitudinal analysis of the competitive profile of products and associated marketing practices of selected European and non-European countries"Journal of International Business Studies, Vol.21, No.3,pp.427-50.

[14] Dornoff, RJ., Tankersley, C.B. and White, G.P. (1974).“Con sumer's percep tion of im ports”, Akron Business and Economic Re view, Vo1.5, No.2, pp.26-9.

[15] Erickson, G. M., Johansson, J. K., \& Chao, P.(1994). Image variables in multi-attribute product evaluations: Country-oforigin effects. Journal of Consumer Research, Vol.11, No.4, pp.694-699.

[16] Ersoy, A., Marka Seçimi Davranışı Ve Marka Seçimine Etki Eden Marka Bağlılığının Davranışsal Boyutu, http://paribus.tr.googlepages.com/a_ersoy.doc, Erişim Tarihi: 10.05.2007.

[17] Gaedake, R. (1973). "Consumer Attitudes Toward Products Made in Developing Countries"; Journal of Retailing, V.49,13-24.

[18] Hallowell, R. (1996).The Relationships of Customer Satisfaction, Customer Loyalty, and Profitability: An Emprical Study, International Journal of Service Industry Management, Vol.7, No.4, pp.27-42.

[19] Han, C. M.(1989). Country image: Halo or summary construct? Journal of Marketing Research, 26, 222- 229(May).

[20] Han CM, Terpstra V.(1988). Country-of-origin effects for uni-national and bi-national products. J Int Bus Stud. Vol.19, pp.535-55(Spring).

[21] Hong, S., \& Wyer, R. Jr. (1991). Determinants of product evaluation: Effects of the time interval between knowledge of a product's country of original information about its specific attributes. Journal of Consumer Research, 17, 277-288(December).

[22] Hong, S.T., Wyer J.R.(1989). "Effects of Country Origin and Product Attribute Information on Product 
Evaluation: An Information Proccessing Perspective”, Journal of Consumer Research: Vol: 16.

[23] Huber J, McCann J. (1982). The impact of inferential beliefs on product evaluations. J Mark Res;19:324-33(August).

[24] Huber, J., \& Puto, C..(1983). Market boundaries and product choice: Illustrating attraction and substitution effect. Journal of Consumer Research, 10, 31-44(June).

[25] Huber, J., \& Zwerina, K. (1996). The importance of utility balance in efficient choice designs. Journal of Marketing Research, 33, 307-317(August).

[26] Iyer, G.R. and Kalita, J.K. (1997). "The im pact of coun try-of-or i gin and coun try-of -man u fac ture cues on con sumer per cep tions of qual ity and value", Jour nal of Global Mar ket ing, Vol. 11, No.1, pp.7-28.

[27] Jacoby, J., Olsen, J. and Haddock, R. (1971). "Price, brand name, and product composition characteristics as determinants of perceived quality", Journal of Applied Psychology,Vol.55, pp.470-79.

[28] Johansson, J. K., Douglas, S. P., \& Nonaka, I. (1985). Assessing the impact of country of origin on product evaluations: A new methodological perspective. Journal of Marketing Research, 22(3), 388396.

[29] Klein JG, Ettenson R, Morris MD. (1998). The animosity model of foreign product purchase: an empirical test in the People's Republic of China. J Mark, 62:89- 100 (January).

[30] Kotler P, Haider DH, Rein I. (1993).Marketing places: attracting investment, industry and tourism to cities, states and nations. New York: Free Press.

[31] Kotler, P.(1984). Marketing Management, Engelwood Cliffs, N.J.: Prentice Hall.

[32] Leonidou, L., Hadjimarcou, J, Kaleka, A..and Stamenova, G. (1999). "Bulgar ian con sum ers' perceptions of prod ucts made in Asia Pa cific", International Mar ket ing Re view, Vol. 16, No. 2, pp.126-142.

[33] Liefeld, J. P.(1993). Experiments on country-of-origin effects: Review and meta-analysis of effect size." In Papadopoulos, N. \& Heslop, L. A. (eds.), Product-country image: Impact and role in international marketing (pp. 117-156). New York: International Business Press.

[34] Maheswaran, D. (1994)."Country of origin as a stereotype: effects of consumer expertise and attribute strength on product evaluations", Journal of Consumer Research, Vol. 21 No. 2, pp.354-65.

[35] March, J. G. (1978). Bounded rationality, ambiguity, and the engineering of choice. Bell Journal of Economics, Vol.9, No.2,pp.587-608.

[36] Nagashima A. (1970). "A Comparison of Japanese and US Consumer Attitudes Toward Foreing Products"; Journal of Marketing; Vol.34, 68-74.

[37] Nakip, M.(2005). Pazarlama Araştırması SPSS Uygulamalı, Seçkin Yayıncılık.

[38] Peterson, A. R., \& Jolibert, A. (1995). A meta-analysis of country-of-origin effects. Journal of International Business Studies, Vol.26, No.4 ,pp.883-899.

[39] Ratneshwar, S., Shocker, A., \& Stewart, D. (1987). Toward understanding the attraction effect: The implications of product stimulus meaningfulness and familiarity. Journal of Consumer Research, 13, 520-533(March).

[40] Samiee, S.(1994). "Costumer evaluation of products in a global market," Journal of International Business Studies, Vol.25, No.3, 579-604.

[41] Savage, L. J.(1954). Foundation of statistics. New York: Wiley.

[42] Sharma A., Shimp, T.S., Shin, J.(1995). "Consumer ethnocentrism: a test of antecedents and moderators," Journal of the Academy of Marketing Science, Vol.23, No.1, 26-37.

[43] Sheng, S., Parker, A., \& Nakamoto, K. (2005). Understanding the mechanism and determinants of compromise effects. Psychology \& Marketing, Vol.22, No.7, 591-609.

[44] Schooler, R.D.(1965). "Product Bias in the Central American Common Market" Journal of Marketing Research; Vol.2, November, pp.394-397.

[45] School er, R. D.(1971). "Bias phe nom ena at ten dant on the mar ket ing of foreign goods in the USA", Jour nal of In ter na tional Busi ness Stud ies, Vol.2, No.1, pp. 71- 80. 104

[46] Terpstra, V.(1995). International Marketing, 3Th Press, pp.3-14.

[47] Tse, D.K. and Gorn, G.J.(1993). "An experiment on the salience of country of origin in the eraofglobalbrands",JournalofĐnternationalMarketing,Vol.1,No.1,pp.57- 76.

[48] Wall, M. and Heslop, L.A. (1986). "Consumer attitudes toward Canadian made versus imported products", Journal of the Academy of Marketing Science, Vo1.14, Summer, pp.27-36.

[49] Wang, C.K. (1978). "The ef fects of for eign eco nom ics, po lit i cal and cultural en vi ron ment on consumer's will ing ness to buy for eign prod ucts", unpub lished doc toral dis ser ta tion, Texas A\&M University, TX.

[50] White, P.D., Cundiff, E. (1978).“Assesing the Quality of Industrial Products”; Journal of Marketing, pp.80-86. 
[51] Wright, P.L.(1975). “Con sumer choice strat e gies: sim pli fy ing vs. optimizing”, Journal of Marketing Research, February, pp.60-7.

[52] Verlegh, P., \& Steenkamp, J. E. M.(1999). A review and meta-analysis of country-of-origin research. Journal of Economic Psychology, Vol.20, 521-546(October).

[53] Zain, O. and Yasin, N. (1997). “The im por tance of coun try-of-or i gin in for - ma tion and per ceived prod uct qual ity in Uzbekistan", In ter na tional Jour nal of Re tail \& Dis tri bu tion Man age ment, Vo1. 25. No. 4, pp.138-145.

[54] Zhang, Y.(1997). "Country of Origin Effect", International Marketing Rewiew: Vol.14, 